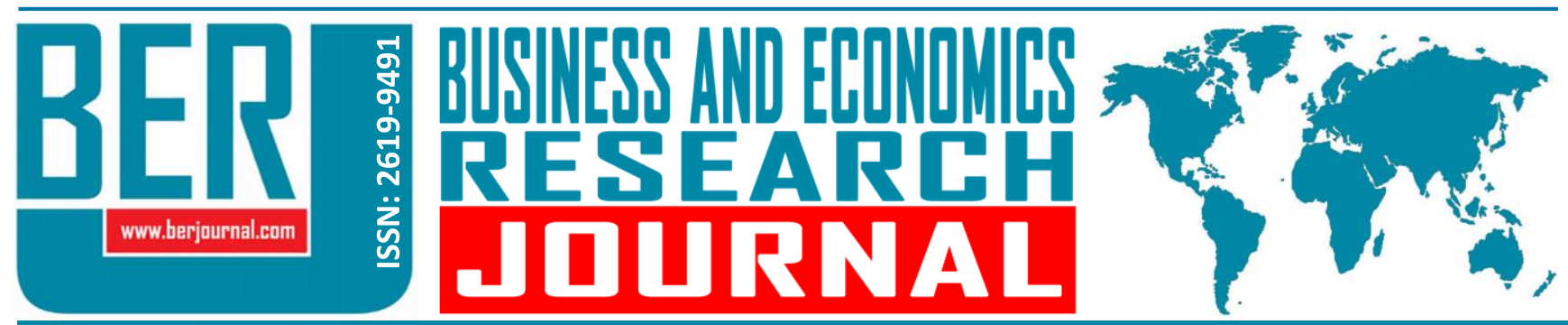

Business and Economics Research Journal Vol. 11, No. 3, 2020, pp. 621-634 doi: 10.20409/berj.2020.273

\title{
Exploring the Linkage between Income Inequality, GDP and Human Well-Being
}

\section{Shashank Vikram Pratap Singh ${ }^{\mathrm{a}}$, Sumanjeet Singh ${ }^{\mathrm{b}}$}

Abstract: The scorning of gross domestic product (GDP) is as old as its birth. Income inequality and ensuring human well-being are few out of many causes of its fulmination. Existing literature on the concern issues reveals that, where there are great disparities in wealth, there are heightened level of social distrust. Poor countries having reasonable distribution of wealth are much better in terms of health and happiness of people than in rich countries having unfair distribution of wealth. It has also been found that, people' health are better in the more equally income distributed societies than the societies having highly skewed distribution of income. It has repercussion effect in the form of reduction of workforces' productivity, upsurge in national expenditures on health, and diversion of resources from prolific endeavours to somewhere else. These are results of growth driven policies which ensure improvements in GDP indicator without assuring improvements in the human well-being. The status of income inequality raises questions on the sustainability of GDP driven development. Hence there is a need for an alternative. This paper is an attempt to discuss the issues concerning rise in income inequality and to shift our focus towards Human Well-Being approach as an alternative to GDP approach.

Keywords: GDP, Income Inequality, Happiness, Human Well-Being

JEL: 131, D63, 047

\section{Introduction}

"It's time we admitted that there's more to life than money, and it's time we focussed not just on GDP, but on GWB-General Well-Being."

David Cameron

GDP usually called an index for measuring economic progress- is estimated by accumulating together the final value $\left(P^{*} Q\right)$ of all the products (be it goods or services or both) that are produced within the domestic territory, in a period of time. Only the products having monetary valuations are considered for the calculation of GDP. Non-monetary items be it goods or services are excluded from the calculation of GDP. Technically, it is measured by adding together, the expenditure of a nation on personal consumption (payment by household for different products), expenditure by government, capital formation (private sector investments) and net export (export - import, X-M), i.e., $Y=C+I+G+(X-M)$ (Keynes \& Rothbarth, 1939). Since last more than half century it is being considered as the most powerful statistical indicator to measure

a University of Delhi, Delhi School of Economic, Department of Commerce, Delhi-7, India, ssvikrampratap@gmail.com (ORCID ID: 0000-0003-3892-8835)

b PhD., University of Delhi, Ramjas College, Department of Commerce, Delhi-7, India, sumanjeetsingh@gmail.com (ORCID ID: 0000-0003-0883-3077) 
progress of nation. Although its historical journey which was started in 1665 by William Petty, reveal that its purpose was different than what it is today. ${ }^{1}$ Keynes writings and thought during 1940 s expanded the notions of Colin, Stone and Kuznets. The prescription given by Keynes was much different from that of Kuznets as it included certain non-welfare (defence \& war related matters) in the national income accounting (Petty, 1676; Kuznets, 1934; Kendrick, 1970; Carson, 1975; Bos, 2006; Mitra-Khan, 2011; Coyle, 2014; Karabell, 2014; Lepenies, 2016). This was the world-shattering moment in the history of GDP. Precisely GDP and its methodology to calculate, were originally constructed in the United States (US) and United Kingdom (UK) in 1930s and 1940s respectively. At that time, the world was in grief of World War (1939-1945) and the Great Depression (1930). Roosevelt was the president of US at that time. His government used the statistical data to defend the policies taken to rescue US out of depression (Carson, 1975). The use of index of economic progress (GDP) as an indicator for measuring economic progress gained further strengthen when Breton Woods Conference took place at New Hampshire. The core thought of the conference was to "speed economic progress everywhere, bring political stability and restore harmony and peace among countries". Its popularity further increased when globally acclaimed and highly reputed institutions like International Monetary Fund (IMF), World Bank, European Central Bank (ECB) and many more stared using it to guide their policies in different part of the world. Even World Bank report (Commission on Growth and Development, 2008) says that "nothing besides long-term high rate of GDP growth can solve the world's poverty problem". In this way, it became the most accepted measure of economic progress.

Many scholars and social scientists including economic science Nobel laureates - Kuznets, 1934, 1941; Hicks, 1948; Samuelson, 1961; Nordhaus and Tobin, 1973; Sen, 1976, 1979; Arrow, et al. 1996; Stiglitz et al., 2010; Stiglitz et al., 2018; Kahneman and Deaton, 2010; Banerjee and Duflo, 2019 - have highlighted that GDP was a measure of economic activities and not the measure of well-being, still it got viewed as a measure of gauging progress across nations. Even, Robert F. Kennedy in one of his address to the faculty and students of University of Kansas on March, $18^{\text {th }} 1968$ said that "GDP measures everything in short except that which makes life more worthwhile". It was the year 1934 when the prominent architect of this index-Simon Kuznets wrote that "services of housewives and other member of the family", "relief and charity", and "earnings from odd jobs", are excluded while measuring GDP (Kuznets, 1934). It only measures the monetary transaction of goods and services, which is not the comprehensive picture of the economic system (Banerjee \& Duflo, 2019). See table 1 and 2 for more convincible argument. ${ }^{2}$

Table 1. The Global Perspective

\begin{tabular}{|l|l|c|c|c|c|c|}
\hline \multicolumn{4}{|c|}{ Size of Economy vs Happiness } & \multicolumn{2}{c|}{ Happiness vs Size of Economy } \\
\hline \multicolumn{2}{|c|}{$\begin{array}{c}\text { Top Five Nations in Terms } \\
\text { of Size of Economy }\end{array}$} & $\begin{array}{c}\text { GDP Per } \\
\text { capita } \\
\text { (current } \\
\text { US \$) } 2018\end{array}$ & $\begin{array}{c}\text { Happiness } \\
\text { Ranking } \\
2019\end{array}$ & $\begin{array}{c}\text { Top Five } \\
\text { Nations in terms } \\
\text { of Happiness } \\
\text { Report 2019 }\end{array}$ & $\begin{array}{c}\text { Size of } \\
\text { Economy }\end{array}$ & $\begin{array}{c}\text { GDP Per } \\
\text { capita } \\
\text { (current US } \\
\$ \text { ) } 2018\end{array}$ \\
\hline USA & $\$ 20.29$ trillion & 62,641 & 19 & Finland & $\$ 273$ Billion & $49,648.1$ \\
\hline China & $\$ 13.60$ tri. & 9770.80 & 93 & Denmark & $\$ 352$ Billion & $60,726.5$ \\
\hline Japan & $\$ 4.97$ tri. & $39,286.7$ & 58 & Norway & $\$ 434$ Billion & $81,807.2$ \\
\hline Germany & $\$ 3.99$ tri. & $48,195.6$ & 17 & Iceland & $\$ 25$ Billion & $73,201.7$ \\
\hline India & $\$ 2.92$ tri. & 2,000 & 140 & Netherlands & $\$ 913$ Billion & $53,0241.1$ \\
\hline
\end{tabular}

Source- World Bank Group Data and Happiness Report, 2019.

Table 2. Top Five Countries Based on Per Capita Nominal GDP and Happiness Index

\begin{tabular}{|c|c|}
\hline Top 5 Countries (Per capita nominal GDP) & Top 5 countries (Happiness Index) \\
\hline Luxemburg & Finland \\
Switzerland & Denmark \\
Norway & Norway \\
Ireland & Iceland \\
Qatar & Netherlands \\
\hline
\end{tabular}

Source: IMF 2019 World Economic Outlook database; Happiness Report, 2019. 
Isn't the table 1 and 2 is conveying some contrasting opinion about GDP vs other aspects of human life and happiness? Can't we equate people's happiness with income? Costanza et al. (2009) noted that human, nature; environment and social fabric are also the part of economic system. However, GDP measure only marketed economic activities and ignored the nature, environment, social and human component of community capital. As a result, GDP fails to measures the key aspects of quality of life. The two reports (WIR, 2018; Oxfam, 2018) which are showing inequality status across world provide extensive data (see Table 3). WIR (2018) mentions the share of top 10 percent earners in 2016 in total national income of different countries (Europe $-37 \%$, China - 41\%, Russia - 46\%, USA - 47\%, and India - 55\%).

Table 3. Top 10 Percent Earners in 2016 as per WIR

\begin{tabular}{|c|c|}
\hline Country/Region & Percentage of Country Population (\%) \\
\hline Middle East & 61 \\
\hline India & 55 \\
\hline US & 47 \\
\hline Russia & 46 \\
\hline China & 41 \\
\hline Europe & 37 \\
\hline
\end{tabular}

Source: WIR, 2018.

There is debate among scholars as to whether inequality is good or bad. Adam Smith is said to have believed that social differences in society are part of divine order and the inequality of rich and poor are natural. He mentioned that it was only the social differences that enabled everyone to live, because, by consumption, the wealthy ensured the livelihood of poor (cited by Lepenies, 2016: 25). It has also been a point of discussion amongst the economists that GDP creates disparity between haves and haves not. Inherent treatment of income distribution is considered to be one of the main objections against GDP as a measure of welfare (Sen, 1976, 1979). Established economist like Sen, Stiglitz and many more argued that GDP per capita is an outcome of measure of central tendency through an average hence the possibility of impact of the presence of extreme value cannot be ignored. Therefore, average income unquestionably highlights that there is unequal distribution of income. This gives rise to the fact that, if there is skewness in income distribution, the possibility of skewness in opportunities available to people for overall wholistic development and being well is also non avoidable. Bernasek (2006) wrote that Income inequality has an adverse impact on the overall poor health condition of people. While echoing with Bernasek's arguments Talberth et al. in 2007 wrote that income inequality increasing crime, reducing worker productivity and reducing investment which further lead to the deterioration of welfare or good state of being of people. Thus, it would not be wrong to wrote that index of economic activity (GDP) is an indicator for measuring economic quantity not economic quality or wellbeing of people.

\section{Human Well-Being as an Approach}

The literal meaning of the word 'Wellbeing'-refers to the state of being comfortable, healthy or happy. It connotes different meaning to different people. There are various factors like sociological, economical, psychological, philosophical and anthropological that significantly affect human 's state of being. Thus, Human Well-being (HWB) is associated with complex interplay of the social, political, economic, religious, ideological and other forces that are around the human being (Estes, 2017). Hence there are various internal and external activities or achievements of people that can affect or constitute a good form of life. ${ }^{3}$ It seems difficult to track all those activities systematically and scientifically to precisely define what constitute HWB. Based on intellectual, political and wartime political climate, scholars, social scientists and practitioners of different periods tried to precisely conceptualise it. Hence the notion of well-being differs from established scholars like Adam Smith, Pigou, Marshal, Hicks, Samuelsson, Colin, Kuznets, Stone, Keynes, Galbraith, and Scitovsky to contemporary scholars like Easterlin, Sen, Diener, Veenhoven, Helliwell, etc. Based on the complexity, Griffin (1986) defined well-being as a part of complex conceptualisations which 
reflects picture of personhood and of science. Up to some extent Felce and Perry (1995) tried to narrow down its operational definition by defining it as an assessment of physical, material, social, emotional and personal state of being of individual through objective descriptors and subjective evaluations. He further wrote that all these set of dimensions should be weighted by a set of value. Ryan and Deci (2001) identified two distinct philosophies surrounding well-being viz., hedonism (reflecting pleasure or happiness) and eudemonism (actualisation of human potential).

While reproducing the ideas of Felce and Perry (1995), Huppert, Baylis and Keverne, (2004) as cited by McAllister (2005) wrote that "at individual level, well-being refers to psychological, physical and social states that are distinctively positive". Gasper (2007) defined well-being through prism of Aristotle when he mentions "well-being is not merely a sensation of happiness". Meaning hereby the aptitudes of human beings are beyond the feeling of happiness, pleasure or pain. Human beings have not only the power of imagination and ability of doing arguments, creation of meaning making reasoning they also have the intra and inter societal links and identities. Thus it is not advisable to look into the construct of wellbeing only with the prism of happiness in literal sense. Well-being is beyond that, Gasper (2002) viewed the notion of well-being "wellbeing referrers to whatever is assessed in an evaluation of a person's situation, or more fittingly and narrowly, in any such evaluation which is focused on the person's being". Having the same broader notion (as discussed above) notion of wellbeing, Travers and Richardson (1993) too describe wellbeing as "abstraction that is used to refer to any of the many well evaluated aspects of human life". Thus from the above discussion, it can be said that, HWB is a concept which represents the many aspects of human life, (McGillivary, 2007). McAllister (2005) wrote "defining well-being is a complex matter" but based on the survey of the literatures, he suggested the following important points ${ }^{4}$;

- Well-being is beyond the absenteeism of illness or pathology.

- Well-being has both subjective (asking individuals opinions about their state of being) and objective dimensions. Meaning hereby the assessment of physical, environmental, social and all other aspect of state of human being. Both these approaches provide the complete picture of state of being or wellbeing of people.

Over the period of time, numerous attempts have been made to conceptualise HWB. During the time of Pigou and Marshall, utilitarian conception of well-being was in practice, which focused on the "Greatest happiness of the greatest Number"which meant higher the income, higher will be the consumption translating into more utility or happiness. Hence income was the standard measure of well-being.Clark, Stone and Kuznets tried to introduce different definition of income and national account, but unfortunately Keynes and Gilbert led wartime politics defeated the notion of inclusion of actual welfare aspect in national account. Utilitarian notion of well-being is based on information hence it will be altogether amazing if moral goodness has nothing to do with well-being (Sen, 1985). The landmark work by Easterlin (1974, 1995, 2001, 2003, 2015), Lane (1991, 1998), Travers and Richardson (1993), MaxNeef (1995), Helliwell (2003), Blanchflower and Oswal (2004), Layard (2003, 2006), Jebb et al. (2018) and many others, bound to change the notion of income as a standard measure of well-being.

From the above discussion it appears to be widespread consensus on the notion of well-being is that of a multidimensionality of wellbeing which includes all the possible and directly or indirectly measurable aspects of human life. Thus on this very hypothesis, different theories have talked and discuss in different discipline that though light on different aspect of wellbeing. Followings are some of the examples of itsubjective well-being approach (Diener, 1984), human capability approach (Sen, 1993), the basic human value approach (Grisez et al., 1987), the intermediate needs approach (Doyal \& Gough, 1991, 1993), the universal psychological needs approach (Ramsay, 1992), the axiological categories approach (Max-Neef, 1995), the universal human value approach (Schwartz 1994), the domains of subjective well-being approach (Cummins, 1996), the dimensions of well-being approach (Narayan et al., 2000) and the central human capabilities Approach (Nussbaum, 2000).

For evaluating or assessing the subjective aspect of human wellbeing, Subjective Well-being (SWB) is used. It (SWB) is used as proxy for quality of life, happiness, satisfaction of people. Thus it is an approach to 
measure the experiences of people related to their quality of life. It is believed that one knows about oneself better than anyone can know about him/her. On this very ground Frey and Stutzer (2002) wrote that "Individuals are the best judges of their quality of life". Therefore it would be the best strategy to directly ask to people a set of questions that reflect their state of being (Frey \& Stutzer, 2002). Thus, through SWB approach an attempt has been made to measure people's moods and emotions that reflect their state of being (Diener \& Suh, 1999). Veenhoven (1993) wrote that the score of individuals on the set of questions of SWB indicates the individual's cognitive assessment that can be used to judge the overall quality of life of individual. For exactly assessing the people's wellbeing different types of questions are used on different levels of scale. In Germany, a single item question on 11-point scale called (GSoEP) German Socio-Economic Panel was adopted. It asks the question like; "how satisfied are you with your life, all things considered"? Among the multiple questions approaches the most prominent is the Satisfaction with Life Scale (SWLS) by Pavot and Diener (1993).

Many scholars have raised questions on the validity of SWB approaches. Afsa et al. (2008) suggested the conditions under which SWB approach is valid. They wrote that- "if the respondents are able to evaluate their life accurately on a numeric scale and have no difficulty in answering the questions; if the respondent understand the questions in way it is written and if the respondent use the same scale as given in the questions" all these three conditions supports the validity of SWB approach (Afsa et al., 2008). But the issue of validity does not end here. The most pertinent question is to what extent these conditions are satisfied? Van Praag (1991) made an attempt to answer this question by suggesting that differences in culture and languages affects the way people understand the questions. Therefore, if such differences exist it may raise question on the validity of SWB approach especially in case of international comparison. Although most studies related with the validity of SWB approach reveal that, the measures of SWB contain a greater deal of validity (Diener, 1994; Diener et al., 1999; Layard, 2006; Kahneman \& Krueger, 2006).

Among all the approaches of wellbeing, capability approach of Amartya Sen is the most influential conception of well-being. Sen (1993) wrote that, well-being is assessed in terms of the capability or freedom or plethora of choices, to achieve valuable 'Doing and Being'. He defined well-being in terms of person's ability to change or to do valuable acts or various valuable functions as a part of living to change the existing states of being. Thus it is clear that 'Doing and Being' is concerned with living, and living is related with various functioning and functioning largely depends on capabilities. Not only this, the functions also differ from people to people (Sen, 1993). Sen (1993) further wrote that some functioning is very basic like being sufficiently nourished, having good health, having educated and access to education and many more. All these basic capabilities are highly essential for the development of an individual. Some functions are very complex like self-esteem, achieving self-respect or being socially integrated.

Over the period of time, the conceptual understanding of wellbeing has changed. Gasper (2007) has nicely conceptualised the ontological assumption for studying and researching the subject matter of wellbeing of people. He categorised the whole studies into the broader categories namely- money-metric focus, non-money metric information and information related to satisfaction. He further elaborated the focused agendas of each categories of broader domain. In this reference the narrower categories likes purchase and other acquisitions, Utility as Choice, and power to acquire goods or commodities has been the most focused agenda in money- metric domain, whereas categories like, functioning, capabilities and characteristics of goods has been under the mon-money-metrics domain and categories likes human fulfilment, utility as satisfaction and utility as desire fulfilment has been categorised under the broader domain of satisfaction information. ${ }^{5}$

Thus from the above discussion it is evidently clear that, HWB lacks a universally acceptable definition and has numerous interpretations. Estes and Sirgy (2017) considered five important sectors of HWB Education, Income, Health, Social Welfare and Wealth distribution. Stiglitz et al. $(2009,2010)$ recommended the fallowing broader construct- "Material living standards (income, consumption, and wealth) Health, Education, Personal activities including work, political voice and governance, social connections and relationship, Environment (present and future conditions), Insecurity of an economic as well as a physical nature". Since 2012, happiness index is calculated based six variables- "GDP per capita, Social support, 
Healthy life expectancy, Freedom to make life choices, Generosity and Perception of corruption" (Helliwell et al., 2019).There is consensus among scholars that the terms like quality of life, life satisfaction, welfare, wellliving, living standard, utility, prosperity, needs fulfilment, development, empowerment, capability expansion, and more recently happiness can be used interchangeably (McAllister, 2005; Layard, 2006; McGillivary, 2007).

\section{Income Inequality and Development}

"Today, there is a huge disparity between the technology, education, health care and agricultural methods that are available in the developed and developing world. The principal challenge we face is to close that gap... The countries, business and individuals that are on the right side of the divide have to think hard about what kind of world they want us all to live in 20 years from now."

Bill Gates.

Income inequality is often associated with the idea of income 'fairness'. It can be fairness of income within the country, between the countries and global as whole. Based on the income fairness Milanovic (2006) explained three types of inequalities, i.e., unweighted income inequality; weighted income inequality; and global or world inequality. Unweighted income inequality is measured based on Gross Domestic Income of the nation which results in measuring only differences in income of the nations and ignore people's income. These shortcomings are removed by weighted income inequality as population is taken into consideration and it gets measured on the basis of Gross Domestic Income Per capita, but it does not disclose the distribution of income within the individuals. Hence for that, Global or World inequality measure is used, which is based on the mean per capita disposal income requiring household survey. The first calculation of global inequality was done in early 1980s (Milanovic, 2006).

There are numerous grounds on the basis of which several social scientist and scholars have fulminated the notion of GDP as the most powerful statistical indicator to measure progress of nation. Income inequality is one of such issue. Over the last many decades it is observed that though economies have grown all across the world, yet inequality has also remarkably widen. It is reported that in India, the share in national income of top $1 \%$ income earners is now at the highest level since the introduction of income tax in 1922. Chancel and Piketty (2017) reported that in India the share of top one percent income earners in 2014 has reached to $22 \%$ in national income. Earlier this particular data was $21 \%$ in 1930 s and $6 \%$ in 1980 s. They have also made very shocking observation, during 1950-1980, bottom 50\% group captured 28 per cent of the total growth and income of this group grew faster than the average, while the income of top $0.1 \%$ earners have decreased. But it is not true during the period of 1980-2014. They further reported that top $0.1 \%$ of earners captured a higher share of total growth than bottom $50 \%$ (12\% vs $11 \%$ ) during $1980-2014$. During the same period top $1 \%$ earners received a higher share of total growth than the middle $40 \%$ earners (29\% vs $23 \%$ ) (Chancel \& Piketty, 2017). Within the OECD, the income of the richest $10 \%$ is on average nine times greater than that of the poorest 10\% (Cassiers \& Thiry, 2014). They further wrote that the past 20 years have witnessed a significant rise in income inequality and relative poverty. When it comes to the picture of global inequality Jackson, (2009) reported that $20 \%$ of the world's population earn $2 \%$ of the global income, whereas the richest $20 \%$ earn $74 \%$ of global income. There is no exception in case of developed nations, inequality has also widen in those nations in last 20 years (Jackson, 2009).

This trend is even evidently clear in both the reports (WIR, 2018; Oxfam, 2018) published in January 2018. According to WIR (2018), $37 \%$ of Europe, $41 \%$ of China, $46 \%$ of Russia, $47 \%$ of US and $55 \%$ of India, consisted of top $10 \%$ earner in 2016. These reports reveal that the Middle East is the most unequal region in the world (top $10 \%$ earners capture $61 \%$ of national income). The other observation of this report is- since 1980 , income inequality has increased rapidly across the globe, but the rate of growth is not equal. Despite rise in economic growth in China and India in last decade, the global inequality has worsened. The data reveal that top $1 \%$ richest individuals in the world captured twice as much growth as the bottom $50 \%$ individual since 1980. Even Oxfam (2018) has made the similar shocking observation. It has reported that 82 per cent 
of all global wealth created in the last year went to the top 1 per cent, while the bottom 50 percent people saw no increase at all. It means globally 3.7 billion people saw no increase in their wealth. In India, 73 per cent of the total wealth created last year went to top $1 \%$ richest.

The above figures on inequality status guide us to mend our way. The focus on GDP has resulted in broadening the gap between rich and the poor as reflected through different reports. Though economists believe that inequality shall rise with economic growth, it is unjustified when we talk of HWB which should ultimately be the goal of all public policies. The state has to develop such policies and facilitating framework to implement these policies for assuring well-being of its people. ${ }^{6}$

Gini Coefficient is the most prominent indicator used globally to measure the income inequality. It is the brain child of Italian statistician Corrado Gini who introduced this concept in 1912 to gauge wealth distribution or more commonly income distribution among population. The coefficient ranges from 0 means perfect equality to 1 means perfect inequality. Interestingly value beyond 1 is also possible theoretically incase of negative wealth or income. Meaning hereby a country having a set of population with same income would have income Gini Coefficient of 0 and if a single resident earned all the income and others earned nothing, then the income Gini Coefficient would be 1. It is quite difficult to measure wealth distribution than income distribution so Gini Coefficient usually reflect income inequality and commonly used as Gini Coefficient. Graphically it is represented through the Lorenz Curve as used by M.O Lorenz in one of his paper in $1905 .^{7}$

\section{Linking Income Inequality with Human Well-Being}

Sen $(1976,1979,1997)$, argued that per capita income is an average distribution of income and such notion is his main objection for considering GDP as measure of welfare. GDP per capita indicate an average income distribution. Hence unequal distribution of income implies that there are unequal opportunities for personal development and well-being. Various academic researchers have scientifically proven its repercussion effect in the overall development of the country. Inequality leads to corruption and low level of trust in the society (You \& Sanjeev, 2005; Ardelyanova \& Obryvalina, 2018) especially in a democratic country where wealth and political power go hand in hand. Thus, more the skewness in the wealth distribution more will be corruption in the society, because with the use of money, policies can be easily manipulated. It further leads to crony capitalism. "If the rich can influence political outcome through lobbying activities or membership in special interest groups, then more inequality could lead to less redistribution rather than more" (Glaeser, Resserger \& Tobio, 2008). This further deepens inequality in society, which hurts economic growth by reducing the efficient allocation of public and private resources and by distorting investment.

Some of the economic dysfunctional aspects of inequality have been highlighted by Wade, (2006) as he mentions that increase in inequality above the moderate level may constrain demand so as the case with economic growth. This vicious cycle may further worsen economic growth. Higher income inequality especially in developing countries, leads to more import of sophisticated goods, which causes downward pressure on labor market. With this effect, inequality further deepens in the society. When inequality rises among countries, residents of poor countries compare themselves with their counterparts residing in rich countries; this forces them to indulge in fraudulent activities to earn beyond the speculative limits (Wade, 2006). When income inequality deeply penetrates into the society (especially in developing countries), it causes more import leading to fall in exchange rate. The state has to pay more on foreign debt which causes reduction in the budget of health, education, and industrial development (Bernasek, 2006; Wade, 2006). Wilkinson (2005) wrote that the condition of average health of population falls as income inequality widen, keeping average income constant. He further wrote that life expectancy in rich countries closely corelate with income inequality. Meaning hereby, higher income inequality low life expectancy and vice versa. Greece is the classic evidence for it. The average income of Greece is about half to that of US but distribution of income is more equal to US as a result of it the life expectancy is higher than that of US (Wilkinson, 2005). This is not only single observation. Several researches have been published and numerous reviews have been done to examine the relation of income inequality and social health (Wilkinson \& Pickett, 2006). The first large review of 98 studies done by Lynch et al. 2004 as cited by Wilkinson \& Pickett (2009), shows that, out 
of 98 studies, 42 percent were found to be wholly supportive (measure of association showed statistically significant relationship between smaller income differences and better health), 25\% were showing partial supportive and 33 percent were showing no support. Wilkinson and Pickett (2006), have done review of 168 studies and classified then in the same categories, out of these analyses $87(52 \%)$ were wholly supportive, 44 (26\%) were partial supportive and $37(22 \%)$ provided no support. Thus having such robust evidences, Wilkinson and Pickett (2007) wrote that, unequal distribution of income was also associated with rate of obesity, teenage birth, mental illness, homicide, low level of trust, low social capital, racism, hostility, poor educational performance among school children, drug overdose mortality, and low social mobility. All these are worse in income unequal society. From the above discussion, it is apparently clear that, inequality severely affect human well-being.

\section{Relationship between GDP, Inequality and Human well-being}

History witnessed that GDP was meant for only valuing the market value of final goods and services produced in the economy. Eminent economists who were aware with GDP and its methodology like Kuznets (1941), Galbraith (1958), Samuelson (1961), and Scitovsky (1976) said that GDP is a specialised tool and it was developed to measure the market value of produced goods and services. Some scholars like Easterlin (1974, 1995); Sen (1976, 1979, 1997); MaxNeef (1995); Frey and Stutzer (2002); Helliwell (2003); Blanchflower \& Oswald (2004); Layard (2006); Jackson (2006, 2009); Talberth et.al. (2007); Costanza et.al. (2009); Stiglitz et.al. (2009); Jeroen (2007, 2009); Afsa et.al. (2008); Goossens et. al. (2007); Posner et.al. (2011); and Antal and Bergh (2014) have vehemently expressed that GDP is not the indicator of everything. One cannot equate well-being with economic growth. Paul Erlich as cited by Nordhaus and Tobin (1973: 2), said "we must acquire a life which has as its goal maximum freedom and happiness for the individuals, not a maximum Gross National Product".

Economy operates in a large system which consists of human capital (people's skill, ability, and health), social capital (friends, neighbours, trust, cooperation, organization and governments), natural resources, natural capital, and ecosystem. Economy benefits from the natural, social, and human capital in terms of raw material and factors of production and grows when output increases and output depends on productivity which is affected from employee motivation and well-being (Diener \& Seligman, 2004). HWB depends on many factors like happiness, quality of life, life satisfaction, and relationship with society and peers but unfortunately economists do not consider these variables while calculating GDP (Felce \& Perry, 1995; Ryan \& Deci, 2001; Easterlin, 2003; McAllister, 2005; Layard, 2006). It ignores changes in natural, social, and human components of community capital on which communities rely for continued existence and wellbeing.

"If we give no value in accounts to the quality of public service; if we remain locked into an index of economic progress that includes only what is created and not what is destroyed; if we look only at GDP, which rise when there has been an earthquake, a fire, or an environmental disaster; if we do not deduced from what we produce what we consume in the course of production; if we do not include the drafts that we are drawing on the future; if we do not take account of how innovation is accelerating capital depreciation- how can we expect to realize what we are really doing and face up to our responsibilities?"8 Thus GDP measures what is measure, rather is being misused as an indicator of something, it does not measure and was never intended to measure.

\section{Concluding Remarks}

From the above discussion it is clear that HWB is a multidimensional concept, which is affected with the numerous activities or achievement and with various economical, sociological, philosophical and psychological aspects of people. Income inequality, directly or indirectly, creates chaos in the social fabric and community capital of society, which has remarkable association with HWB. It is well recognised that it is difficult to quantify all aspects of well-being. Per capita income was such one attempt after Second World War. Inspite of lots of fulmination, it is still used and regarded as the world's most powerful statistical indicator. Recent reports are clearly indicating that, there is deep division among haves and haves not all 
across the globe. Economic growth is consistently increasing in every part of the world since last many decades, but at the same time there is high skewness in income distribution as well. In year 2016, 82 percent of total generated wealth went to top $1 \%$ of the richest individual while $50 \%$ of the world's population saw no increase in their income. It reflects that there is very serious problem in the existing indicator to measure progress of nation. It gives an alarming indication towards shift in policy orientation at government level.

In the academic world the lots of talks is going on whether income fully capture the complexities of HWB or not? Most of the thinkers now start believing that income alone adequately cannot define Human wellbeing. In response to it, since 1970s policymakers and practitioners have increasingly relied on the broad range of social indicators which cover broad range of variables like, health, education, standard of living, pollution, crime, value of leisure, happiness, quality of life, governance, inequality, sustainability and basic human rights. As a result of it many alternative indicators like, Measure of Economic Well-being, Index for sustainable economic well-being, Genuine Progress Index, Human Development Index, Happy Planet Index, Physical Quality of Life index, Gross National Happiness, Subjective Well-being etc have been developed in many parts of the word.

As argued throughout the paper it is suggested that the focus of the public policy should lie in developing better social infrastructure and the priority of expenditure should be on investing in such activities like education, health, sanitation, electricity, better roads etc apart from assuring better and faster governance. We should be comparing the status of HWB across nation and other geographies for framing appropriate policies rather than concentration on GDP measure. Over emphasis on GDP has resulted in broadening the gap between the rich and the poor which could be handled better with the policies focusing on improving quality of life of people and better Human Well Being.

\section{Disclosure Statements}

1. The authors of this article confirm that their work complies with the principles of research and publication ethics.

2. No potential conflict of interest was reported by the authors.

3. This article was screened for potential plagiarism using a plagiarism screening program.

\section{Acknowledgment}

We are grateful to three anonymous reviewers for constructive criticisms and suggestions. The usual disclaimer applies.

\section{End Notes}

1. Petty, 1676; Smith, 1776; Clark, 1932; Kuznets, 1934, 1941; Keynes, 1936; Gilbert, 1942, 1943; Kendrick, 1970; Carson, 1975; Landelfeld, et al. 2009; Krueger, 2003; Bos, 2006; Marcuss and Kane, 2007; Tily, 2009; Mitra-Khan, 2011; Coyle, 2014; Karabell, 2014; Lepenies, 2016.

2. India's case can be taken to illustrate the contradiction between the size of economy and other aspects of human life. India is approximately USD 10 trillion (PPP) and \$2.92 trillion (Nominal) economy (Table 1), which enables it to become the third and fifth largest (respectively) in the world. Despite having this chest thumbing statistical data, the condition of 'state of being and state of lives' of people of India is as follows: The per capita income at the current dollar is around $\$ 2,000$ which is less than the world average of $\$ 10,722$. It stands at 129th place in HDI ranking, 140th in Happiness Index, 147th in World Inequality Index, 141st in Global Peace Index, 140th in World Press Freedom Index, 78th in Corruption Perception Index, 115th in Human Capital index, 102nd in global hunger index, 110th in Human Freedom Index, 177th in Environmental Performance Index, 145th in Healthcare Access and Quality Index, 112th in WEF's Global Gender Gap Report \& 149th place on providing economic participation and opportunity to women and 
62nd in Inclusive Development Index. The present doctor-patient ratio is around 1:10000 as compared to the WHO prescribed limit of 1:1000. India has 7 beds per 10,000 people while the global median is 27 per 10,000 people. For more see Shrotryia and Singh (2019).

3. For detailed discussion, read Estes \& Sirgy (2017), The Pursuit of Human Well-being - The Untold Global History. (p 3-82).

4. For detail see McAllister (2005).

5. See for details Gasper (2007).

6. For more on income inequality see. Atkinson (1970), Stiglitz (2012), Piketty (2014).

7. For more on Gini coefficient see-Atkinson (1970), Alison (1978), Thewissen et al. (2015), Gastwrith (2017).

8. The statement is taken from the book title Mis-measuring our lives Why GDP does not Add Up, by Joseph Stiglitz, Amartya Sen and Fitoussi (2009) in which Nicolas Sarkozy has written the Foreword section.

\section{References}

Afsa, C., Blanchet, D., Marcus, V., Pionnier, P. A., \& Rioux, L. (2008). Survey of existing approaches to measuring socioeconomic progress. Paper for the Commission on the Measurement of Economic Performance and Social Progress, OECD.

Alison, P. (1978). Measurement of inequality. American Sociological Review, 43, 865-880.

Antal, M., \& Jeroen, B. V. (2014). Evaluating alternative to GDP as measures of social welfare/ progress. European Commission European Research Area. Retrieved March 20, 2020 from https://ec.europa.eu/social/BlobServlet?docld=12760\&/angld=en

Ardelyanova, Y., \& Obryvalina, O. (2018). Comparative analysis of inequality, corruption, and trust studies in modern societies. Mediterranean Journal of Social Sciences, 9(1), 65-69.

Arrow, K., Bolin, B., Costanza, R., Dasgupta, P., Folke, C., \& Holling, C. S. (1996). Economic growth, carrying capacity, and the environment. Environment and Development Economics, 1(1), 104-110.

Atkinson, A. (1970). On the measurement of inequality. Journal of Economic Theory, 22, 244-263.

Atkinson, A. (2015). What can be done? Harvard University Press.

Banerjee, A. V., \& Duflo, E. (2019). Good Economics for Hard Times. New Delhi. Juggernaut Books.

Bernasek, A. (25 June, 2006). Income inequality and its cost. The New York Times. Retrieved August 20, 2017 from http://www.nytimes.com/2006/06/25/business/yourmoney/25view.html

Blanchflower, D. G., \& Oswald, A. J. (2004). Well-being over time in Britain and the USA. Journal of Public Economics, 88(7-8), 1359-1386.

Bos, F. (2006). The national accounts as a tool for analysis and policy: Past, present and future. MRPA Papers.

Carson, C. S. (1975). The history of the United States national income and product accounts: the Development of an analytical tool. Review of Income and Wealth, 21(2), 153-181.

Cassiers, I., \& Thiry, G. (2014). A high- stakes shift- turning the tide from GDP to new prosperity indicators. Discussion Paper 2014-2.

Chancel, L., \& Piketty, T. (2017). Indian Income Inequality, 1922-2015: From British Raj to Billionaire Raj? WID, Working Paper Series N- 2017/11.

Clark, C. (1932). The National Income 1924-1931. London: Macmillan \& Co.

Commission on Growth and Development, (2008). The growth report: Strategies for sustained growth and inclusive development. Washington, DC: World Bank.

Costanza, R., Hart, M., Posner, S., \& Talbert, J. (2009). Beyond GDP: The need for new measures of progress. Pardee Paper No. 4, Boston: Pardee Center for the Study of the Longer-Range Future.

Coyle, D. (2014). GDP-A brief but affectionate history. Princeton University Press.

Cummins, R. A. (1996). Domains of life satisfaction: An attempt to order chaos. Social Indicators Research, 38(3), 303328.

Diener, E. \& Suh, E. M. (1999). National differences in subjective well-being. In D. Kahneman, E. Diener \& N. Schwarz (Eds.), Well-being: The foundations of hedonic psychology (434-450). New York: Russell Sage Foundation. 
Diener, E., Suh, E. M., Lucas, R. E., \& Smith, H. L. (1999). Subjective Well-being; three decades of progress. Psychological Bulletin, 125, 276-303.

Diener, E. (1984). Subjective well-being. Psychological Bulletin, 95(3), 542-575.

Diener, E. (1994). Assessing subjective well-being: Progress and opportunities. Social Indicators Research, 31, $103-157$.

Diener, E. (2000). Subjective well-being. The science of happiness and a proposal for a national index. American Psychologist, 55, 34-43.

Diener, E. (2006). Guidelines for national indicators of subjective well-being and ill-being. Journal of Happiness Studies, 7, 397-404.

Diener, E., \& Seligman, M. E. P. (2004). Beyond money: Towards an economy of well-being. American Psychological Society, 5(1), 1-31.

Doyal, L. \& Gough, I. (1991). A theory of human need. London: Macmillan.

Doyal, L. \& Gough, I. (1993). Need satisfaction as a measure of human welfare. In W. Blass \& J. Foster (Eds.), Mixed economies in Europe. London: Edward Elgar.

Easterlin, A. R. (1974). Does economic growth improve the human lot? Some empirical evidence. In R. David \& R. Reder (Eds.), Nations and households in economic growth: Essays in honor of Moses Abramovitz, Academic Press, New York.

Easterlin, R. A. (1995). Will raising the incomes of all increase the happiness of all? Journal of Economic Behavior and Organization, 27(1), 35-47.

Easterlin, R. A. (2001). Income and happiness: Towards a unified theory. Economic Journal, 111(473), 465-484.

Easterlin R.A. (2015) Happiness and Economic Growth - The Evidence. In W. Glatzer, L. Camfield, V. Moller, \& M.Rojas (Eds.), Global handbook of quality of life (pp. 283-299). International Handbooks of Quality-of-Life. Dordrecht: Springer.

Easterlin, A., R. (2003). Building a better theory of well-being. IZA Discussion Paper, No- 742.

Estes, R. J. \& Sirgy, M. (2017). The Pursuit if human well-being, the untold global history. Switzerland: Springer International Publication.

Estes, R. J. (2017). The search for well-being: From ancient to modern times. In R. J Estes \& M. Siraj (Eds.), The pursuit of human well-being (1-30). Springer International Publication.

Felce, D., \& Perry, J. (1995) Quality of life: Its definition and measurement. Research in Developmental Disabilities, 16(1), 51-74.

Frey, B. S., \& Stutzer, A. (2002). What can economists learn from happiness research? Journal of Economic Literature, 40, 402-435.

Galbraith, J. K. (1958). The affluent society. Houghton Mifflin Company, Boston.

Gasper, D. (2002). Is Sen`s capability approach an adequate basis for considering human development? Review of Political Economy, 14(4), 453-61.

Gasper, D. (2007). Human well-being, concept and conceptualisation. In M. McGillivery (Ed.), Human well-being: Concept and measurement. Landon: Palgrave Macmilan.

Gastwirth, J. L. (2017). Is the Gini index of inequality overly sensitive to changes in the middle of the income distribution? Statistics and Public Policy, 4(1), 1-11.

Gilbert, M. (1942). Measuring National Income as Affected by the War. Journal of the American Statistical Association, 37(218), 186-198.

Gilbert, M. (1943). U.S. National income statistics. The Economic Journal, 53(209), 76-82.

Glaeser, L. E, Resserger, M. G., \& Tobio, K. (2008). Urban inequality. Working paper 14419, National Bureau of Economic Research.

Goossens, Y., Makipaa, A., Schepelmann, P., van de Sand, I., Kuhndt, M., \& Herrndorf, M. (2007). Alternative progress indicators to gross domestic product (GDP) as a means towards sustainable development. Policy Department Economic and Scientific Policy, European Parliament.

Griffin, J. (1986). Well-being: Its meaning, measurement and moral importance. Oxford: Claredom Press.

Grisez, G., Boyle, J., \& Finnis, J. (1987). Practical principles, moral truth, and ultimate ends. American Journal of Jurisprudence, 32, 99-151. 
Helliwell, J. (2003). How's life? Combining individual and national variations to explain subjective wellbeing. Economic Modelling, 20, 331-360.

Helliwell, J., Layard, R., \& Sachs, J. (2019). World happiness report 2019. Sustainable Development Solution Network.

Hicks, J. (1948). Value and capital. Oxford: Oxford University Press.

Jackson, T. (2006). Beyond the well-being paradox: Well-being, consumption growth, and sustainability. CES Working Paper 06/06, Centre for Environmental Strategy, University of Surrey.

Jackson, T. (2009). Prosperity with growth: Economics for a finite planet. London Earthscan Publication.

Lane, R. E. (1991). The market experience. New York: Cambridge University Press.

Lane, R. E. (1998). The road not taken: Friendship, consumerism and happiness. In D.A. Crocker \& T. Linden (Eds.). Ethics of consumption- the good life, justice and global stewardship (pp.218-248). Lanham, MD: Rowman and Littlefield.

Jebb, A. T., Tay, L., Diener, E., \& Oishi, S. (2018). Happiness, income satiation and turning points around the world. Nature Human Behaviour, 2(1), 33-38.

Jeroen, B. (2007). Abolishing GDP. Tinbergen Institute Discussion Paper TI 2007-019/3.

Jeroen, B. (2009). GDP paradox. Journal of Economic Psychology, 30(2009), 117-135.

Kahneman, D., \& Deaton, A. (2010). High income improves evaluation of life but not emotional well-being. Proceedings of the National Academy of Sciences of the United States of America, 107(38), 16489-16493.

Kahneman, D., \& Krueger, A. B. (2006). Developments in the measurement of subjective well-being. Journal of Economic Perspectives, 20(1), 3-24.

Kahneman, D., Krueger, A. B., Schkade, D., Schwarz N., \& Stone, A. (2004). Toward national well-being accounts. American Economic Review, Papers and Proceedings, 94, 429-434.

Karabell, Z. (2014). The leading indicators: A short history of the number that rule our world. Simon \& Schuster.

Kendrick, J. W. (1970). The historical development of national-income accounts. History of Political Economy, 2(2), 284315

Kennedy, R. F. (March 18, 1968). Retrieved January 15, 2020 from https://www.jfklibrary.org/Research/ResearchAids/Ready-Reference/RFK-Speeches/Remarks-of-Robert-F-Kennedy-at-the-University-of-Kansas-March-181968.aspx

Keynes, J. M. (1936). The general theory of employment, interest and money. London: Macmillan \&Co.

Keynes, J. M. (1940). How to pay for the war. A radical plan for the chancellor of the exchequer. Melbourne: Macmillan $\&$ Co.

Keynes, J. M., \& Rothbarth, E. (1939). The income and fiscal potential of Great Britain. Economic Journal, 49(196), 626639.

Krueger, A. B. (2003). (ed.) The wealth of nations - Adam Smith. New York: Bantham Classics.

Kuznets, S. (1934). National income, 1929-32, 1934. National Bureau of Economic Research, New York.

Kuznets, S. (1941). National income and its composition 1919-1938. National Bureau of Economic Research, New York.

Landefeld, J. S., Moulton, B. R., Platt, J. D., \& Villones, S. M. (2009). GDP and beyond: Measuring Economic Progress and Sustainability. Bureau of Economic Analysis.

Layard, R. (2006). Happiness: Lessons from a new science. London: Penguin Books.

Layard, R. (2003). Lecture 2. Income and happiness : Rethinking economic policy. Lionel Robbins Memorial Lectures.

Lepenies, P. (2016). The power of a single number, a political history of GDP. New York: Columbia University Press.

Marcuss, R. D., \& Kane, R. E. (2007). U.S. national income and product statistics: Born of the Great Depression and World War II. Bureau of Economic Analysis: Survey of Current Business.

MaxNeef, M. (1995). Economic growth and quality of life: A threshold hypothesis. Ecological Economics, 15(2), 115-118.

McAllister, F. (2005). Well- being concepts and challenges. Discussion paper prepared for Sustainable Development Research Network.

McGillivary, M. (2007). Human well-being: Issue, concepts and measures. In M. McGillivery (Ed.), Human well-being: Concept and measurement. Studies in Department Economics and Policy. Landon: Palgrave Macmillan.

Milanovic, B. (2006). Global income inequality: What it is and why it matters? Economic and Social Affair (UN), Working Paper No. 26. 
Mitra-Kahn, B. H. (2011). Redefining the economy: How the economy was invented 1620. City University London, Unpublished Doctoral Thesis.

Muller, E. N., \& Seligon, M. A. (1987). Inequality and insurgency. The American Political Science Review, 81(2), $425-452$.

Narayan, D., Chambers, R., Shah, M. K., \& Petesch, P. (2000). Voices of poor: Crying out for change. Oxford University Press.

Nordhaus, W., \& Tobin, J. (1973). Is growth absolute? In M. Moss (Ed), The measurement of economic and social performance (pp.509-564). National Bureau of Economic Research, Inc.

Nussbaum, M. C. (2000). Women and human development: The capabilities approach. Cambridge University Press.

Oxfam, (2018). Reward work, not wealth. Oxfam International.

Piketty, T. (2014). Capital in the twenty-first century. Harvard University Press.

Petty, W. (1676). Essay on mankind and political arithmetic. Cossel \& Co.

Posner, S., \& Robert, C. (2011). A summary of ISEW and GPI studies at multiple score and new estimates for Baltimore City, Baltimore Country and the State of Maryland. Ecological Economics, 70(11), 1972-1980.

Povot, W., \& Diener, E. (1993). The effective and cognitive context of self-reported measures of subjective well-being. Social Indicator Research, 28(1), 1-20.

Ramsey, M. (1992). Human needs and market. Aldershot: Avebury.

Ryan, R., \& Deci, E. (2001). On happiness and human potential: A review of research on hedonic and eudemonic wellbeing. Annual Review of Psychology, 52, 141-166.

Samuelson, P. A. (1961). The evaluation of social income: Capital formation and wealth. In F. Lutz \& D. Hague (Eds), The theory of capital. New York: St. Martin's Press.

Schwartz, S. H. (1994). Are there universal aspects in the structure and contents of human value? Journal of Social Issues, $50,19-54$.

Schwartz, S. H. (2005). Basic human values: Their content and structure across countries. In A. Tamayo \& J. B. Porto (Eds.), Values and behaviour in organisation (pp. 21-55).

Scitovsky, T. (1976). The joyless economy. New York: Oxford University Press.

Sen, A. (1976). Real national income. Review of Economic Studies, 43(1), 19-39.

Sen, A. (1979). The welfare basis of real income comparisons. Journal of Economic Literature, 17(1), 1-45.

Sen, A. (1985). Well-being, agency and freedom: The Dewey lectures, 1984. The Journal of Philosophy, 82(4), $169-221$.

Sen, A. (1993). Capability and well-being. In M. Nussbaum \& A. Sen (Eds), The quality of life (pp.30-53). Oxford: Clarendon Press.

Sen, A. (1997). Distinguished guest lecture, from income inequality to economic inequality. Southern Economic Journal, 64(2), 384-401.

Shrotryia, V. K., \& Mazumdar, K. (2017). The history of well-being in south Asia. In R. Estes \& M. Sirgy (Eds.), The pursuit of human well-being: The untold global history (pp. 349-380). Cham, Switzerland: Springer.

Shrotryia, V. K., \& Singh, S. V. P (2019). In defence of inclusion of happiness in public policy for India. India Policy Foundation. New Delhi, India.

Smith, A. (1976). Inquiry into the nature and causes of the wealth of nations. W. Strahan and T. Candell, London.

Stieglitz, J., Sen, A., \& Fitoussi, J. (2010). Mismeasuring our lives: Why GDP does not add up. The New Press.

Stiglitz, J., Fitoussi, J., \& Durand, M. (2018). Beyond GDP: Measuring what counts for economic and social performance. OECD. Retrieved January 10, 2020 from https://www.oecd.org/corruption/beyond-gdp-9789264307292-en.htm

Stiglitz, J. (2012). The Price of inequality. London: Penguine.

Stiglitz, J. E., Sen, A., \& Fitoussi, J. P. (2009). Report by the Commission on the Measurement of Economic Performance and Social Progress. Retrieved February 10, 2020, from http://files.harmonywithnatureun.org/uploads/upload112.pdf

Sung, Y. J., \& Khagram, S. (2005). A comparative study of inequality and corruption. American Sociological Review, 70, 136-157.

Talberth, J., Cobb C., \& Slattery, N. (2007). The Genuine progress indicator 2006: A tool for sustainable development. Redefining Progress, Oakland, California. 
Thewissen, S., Kenworthy, L., Nolan, B., Roser, M., \& Smeeding, T. (2015). Rising income inequality and living standards in OECD countries: How Does the middle fare? LIS Working Paper series, No. 656.

Tily, G. (2009). John Maynard Keynes and the development of national accounts in Britain, 1895-1941. Review of Income and Wealth, 55(2), 331-359.

Travers, P., \& Richardsan, S. (1993). Material well-being and human well-being. Summary in F. Ackerman, D. Kiron, N.R. Goodwin, J. M. Harris \& K. Gallagher (Eds.), 1997, Human well-being and economic goals (pp. 26-39). Washington DC: Island Press.

Van Praag, B. M. (1991). Ordinal and cardinal utility, an integration of the two dimensions of welfare concept. Journal of Econometrics, 50, 69-89.

Veenhoven, R., (1993). Happiness in nation: Subjective appreciation of life in 56 nations, 1946-1992. Erasmus University Rotterdam Press.

Wade, R. H. (2006). Should we worry about income inequality? International Journal of Health Service, 36(2), 271-294.

Wilkinson, R. G \& Pickett, E. K. (2009). Income inequality and social dysfunctional. Annual Review of Sociology, 35, 493511.

Wilkinson, R. G. (2005). The impact of inequality: How to make sick societies healthier. The New Press.

Wilkinson, R. G., \& Pickett, E. K. (2006). Income inequality and population health: A review and explanation of the evidence. Social Science \& Medicine, 62, 1768-1784.

Wilkinson, R. G., \& Pickett, E. K. (2007). Problems of relative deprivation: Why some society doo better than other. Social Science Medicine, 62, 1768-1784.

World Inequality Report (WIR), (2018). Published by World Inequality Lab. Retrieved March 10, 2020 from http://wir2018.wid.world/files/download/wir2018-full-report-english.pdf

You, J. S., \& Sanjeev, K. (2005). A comparative study of inequality and corruption. American Sociological Review, 70(1), 136-157. 